\title{
Co-innovation at Mercadona: a radically different and unique innovation model in the retail sector
}

\author{
Miguel Blanco-Callejo \\ Rey Juan Carlos University, Spain \\ Carmen de Pablos-Heredero \\ ESIC Business \& Marketing School and Rey Juan Carlos University, Spain
}

\section{Keywords}

Co-innovation, Competitive Advantage, Dynamic Capabilities, Retail Industry, Uniqueness

\begin{abstract}
The purpose of this paper is to describe through an exploratory case study how the leading retailing company in Spain, Mercadona has been able to generate a set of dynamic capabilities - detection, absorption, integration and innovation - that support an original and unique innovation model in the retail sector. This model drives to higher rates of successful product innovation, a constant updating of its range of products according to the ever-changing consumers' needs and outstanding results in terms of reputation and customer loyalty. Thanks to a sustained investment in product innovation and supported by solid theoretical frameworks such as Dynamic Capabilities and Open Innovation Mercadona has been able to develop this pioneering model which could be an interesting benchmark for the industry as well as stimulate future research regarding retailers' role and involvement in product innovation.
\end{abstract}

Corresponding author: Miguel Blanco-Callejo

Email addresses for the corresponding author: miguel.blanco@urjc.es

First submission received: $14^{\text {th }}$ March 2018

Revised submission received: $5^{\text {th }}$ February 2019

Accepted: $13^{\text {th }}$ April 2019

\section{Introduction}

Retail companies face an extremely dynamic environment because customers' needs, and preferences are changing at an increasingly rapid pace. Given the fact that retailers traditionally just connect suppliers' offer and final consumers' demand, they do not invest enough in product innovation and they assign this job and cost to their suppliers.

Mercadona, a Spanish family-run retailer operating with a sole format - around 1,500 $\mathrm{m}^{2}$ strategically located urban supermarkets - has become the leading company in the national market as well as an international benchmark due to its outstanding results (Silverstein; Bolden; Jacobsen and Sajdeh, 2015). Mercadona has a share of $16.5 \%$ of the total retail distribution space (Alimarket, 2016) and a market share in 2017 of 23.6\% (Kantar World Panel, 2017). In 2016, the company had a turnover of 21,623 million and a Net Profit of 636 million $€$ (Mercadona, 2017). This firm has broken away from the industry's traditional approach by investing heavily in product innovation with the strategic goal of being unique and differentiating its range of products. The result has been a new "Co-innovation" model, based on solid theoretical foundations such as Open Innovation and Dynamic Capabilities.

\section{Literature Review}

Open innovation is a key factor in organizations' growth and sustainability (Chesbrough, 2006; West 2016). In the economy of experience (Pine and Gilmore, 1999), the competitive environment makes necessary for innovation to become a tool for structuring a complex business ecosystem, in which stakeholders are increasingly interconnected and interdependent. Consumers' involvement in the product innovation process increases emotions that affect its perceived value (Franke; Keinz and Steger, 2009; Lee and Chang, 2011). Special key players in this innovation process are "lead users", advanced users \& consumers that clearly express their products' preferences, with which they are completely familiar and 
have enormous potential for offering opinions on how to improve them (Von Hippel, 1986; Franke et al., 2009).

From a practical perspective, one of the initiatives in which user participation experiences are being developed are the "living labs". These are experimental spaces in which organizations, by providing the infrastructure and regulating mechanisms, can capture users' opinions developing and validating products and services jointly. These labs promote research in the context in which products and services are used, discover unexpected uses for products \& services and therefore new opportunities, involve users as co-creators, evaluate and validate new solutions with users and, finally provide technical evaluations in real or almost real contexts (Folstad, 2008).

This collaborative and repetitive interaction between consumers and companies generates organizational routines (Nelson and Winter, 1982) that according to the Resource-Based-View of the firm (Barney, 1991) explain the development of dynamic capabilities (Teece; Pisano and Shuen, 1997). A dynamic capability is a learned and stable pattern of collective activity, through which the organization is capable of generating and constantly changing its operating routines, in the search for increased efficiency (Woiscehyn and Dallenbach, 2005). For $\mathrm{Hu}$ (2012), there are four basic components of dynamic capabilities. First, the capability of detection, as the ability to detect the environment and understand customer needs better than competitors (Amit and Schoemaker, 1993). Second, the capability of absorption, which refers to the ability to recognize the value of something new, assimilate the information and apply it for commercial purposes (Cohen and Levinthal, 1990). Third, the capability of integration, which is the ability to integrate different patterns of interaction through contribution, representation and interrelation (Okhuysen and Eisenhardt, 2002) and, finally the capability of innovation, which is the ability to develop new products and markets by coordinating strategic targets; with innovating behavior and processes (Lazonick and Prencipe, 2005).

\section{Research Methodology}

In order to observe dynamic capabilities development as well as the initiatives implemented within the economy of experience and open innovation frameworks, this paper uses an exploratory case study as its research methodology. Academic literature suggests that methodology's choice is contingent on the problems and questions studied as well as the development of the area of knowledge (Eisenhardt, 1989; Yin, 1994; Hancock and Algozzine, 2015). A single case study seems suitable to develop this research since it satisfies Yin's (1994) basic premises. First, the researcher aims to test a theory that specifies a set of results in a situation and an organization where this situation has been identified. Second, the researcher aims to analyze some features of an extreme, rare or extraordinary situation in which the organization is found, the methodology can be employed to compare and contrast. Third, this methodology can be used to analyze an organization or situation that has not been frequently studied and can expect to apprehend something new and important. Hence, Mercadona has implemented a radically new strategic approach regarding product innovation in retailing that has made the firm unique in the way it has developed and configured its model which is contributing to its leadership in the industry.

\section{Findings/Results: Case-study Analysis \\ Mercadona's Management Model}

One of Mercadona's key features is the fact that, through its Total Quality Management Model (TQM) (Blanco and Gutierrez, 2008), it strives to avoid appearing as a mere distributor, but rather as a total shopping prescriber (totaller) (Mercadona, 2007; Silverstein et al., 2015). Its corporate mission is "being a prescriber of the solutions required by customers - internally called "bosses (jefes)" - to manufacture all their purchases" (Mercadona, 2010 - 2017). This means that Mercadona chooses a range of products and plays the role of "prescriber" between suppliers and customers recommending and guaranteeing purchasing to cover the total - (totaller) - of all its customers' real needs in food, beverages, hygiene \& personal care, household cleaning products and pet food.

Each one of Mercadona's stores has approximately 8,000 Stock Keeping Units (SKUs) provided by "chosen specialist suppliers". Its value proposition is providing the best range of top quality prescribed products at the very best possible price (based on the principle of Always Low Prices) allowing customers 
to fill their "shopping trolley" - with the best value for money on the market - (Mercadona, 2011). Customers' acceptance of the range requires maintaining a close relationship connecting with them as well as the development of a series of Dynamic Capabilities - detection, absorption, integration and innovation - that enable Mercadona to adapt constantly its products' range to their ever-changing needs. This objective, consistent with its TQM model (Blanco and Gutiérrez, 2008), requires the efforts and work of employees and suppliers and a commitment towards "leveraged" innovation \& investment that empowers Mercadona to anticipate changes in consumption habits and new customer needs (Mercadona, 2012).

Innovation at Mercadona is measured in terms of value added, which is defined as: "anything that fulfills a customer's need and provides a solution" (Mercadona, 2009:33). Regarding innovation, in 2011, its approach took a strategic turn to define its own "differential" model breaking away from the traditional method where the suppliers invest in product research and development (R\&D) and propose new products to retailers' product selection departments (Almenar, 2016). Mercadona's innovation model directly involves its customers in the product innovation process as well as in the definition of its products' range (Figure 1). The final objective of this model was to be able to receive and capture what customers really demand to adapt and offer solutions that meet their real needs "delighting and surprising" them (Silverstein et al., 2015:172).

Figure 1. Mercadona's model vs. Retailers' Traditional Model

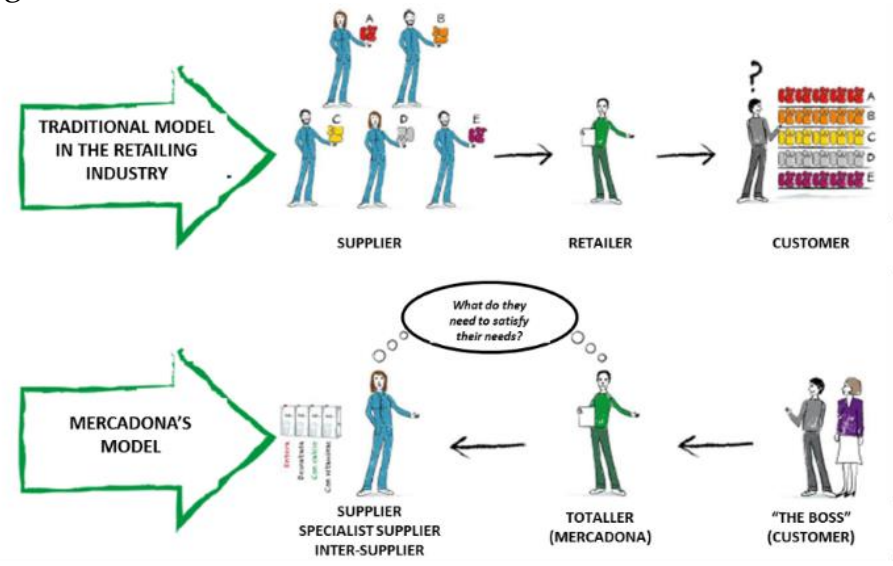

Source: Mercadona (2017)

Mercadona's product innovation model is based on "R\&D + Innovation, supported by leveraged investment - required for achieving results from innovation -" (R\&D+ double " $\mathrm{i}$ ") (Mercadona, 2010). Under this paradigm, it has developed its strategical priority model of radical co-innovation with active and direct customer participation searching to adapt its range and products with greater ease and accuracy to bosses' real needs (Mercadona, 2011:29; Institut Cerdá, 2016). The model is oriented towards "introducing improvements that provide solutions to customers that they are willing to pay for" (Mercadona, 2011:29) and comprises "everything that meets bosses' needs and provides solutions that imply select initiatives, competitive prices, ongoing quality improvement and commercial creativity" (Mercadona, 2009:33-34).

\section{A Product Innovation Model based on the Development of Dynamic Capabilities}

Mercadona's "prescription" process is oriented towards achieving an "effective range" of unique products manufactured by specialist suppliers that enables it to differentiate and to stand out from its competitors and directly involve its customers and suppliers (Mercadona, 2017). This process requires the construction and development of a series of organizational routines that have generated dynamic capabilities extremely difficult for its competitors to copy and replicate. The generation and development of these capabilities (Table 1) requires staff commitment, "bosses'" collaboration, direct interaction and proximity and, finally, the involvement of suppliers that manufacture products that meet customers' real needs. 
Table 1- Mercadona's prescription process and dynamic capabilities generated

\begin{tabular}{|c|c|c|c|c|}
\hline MERCADONA & Process Phases & Key players/agents & Tools & $\begin{array}{l}\text { Dynamic } \\
\text { Capabilities }\end{array}$ \\
\hline \multirow[t]{4}{*}{ CAPTURE } & Identify "bosses-consumers in love" & Monitors & $\begin{array}{l}\text { Interaction with customers at } \\
\text { stores }\end{array}$ & DETECTION \\
\hline & File "bosses in love" data & $\begin{array}{l}\text { Monitors and } \\
\text { Prescription } \\
\text { Coordinators }\end{array}$ & $\begin{array}{l}\text { Filing "bosses in love" personal } \\
\text { details and availability }\end{array}$ & ABSORPTION \\
\hline & $\begin{array}{l}\text { Invite "bosses in love" to share experiences } \\
\text { on the use/consumption of products }\end{array}$ & Monitors & $\begin{array}{l}\text { Meeting with "bosses in love" at } \\
\text { their homes or at the Co- } \\
\text { innovation Center }\end{array}$ & ABSORPTION \\
\hline & $\begin{array}{l}\text { Compile specific information on customer } \\
\text { experiences with products }\end{array}$ & Monitors & $\begin{array}{l}\text { Written notes recording "bosses } \\
\text { in love" comments, reactions, } \\
\text { perceptions }\end{array}$ & ABSORPTION \\
\hline DEFINE & $\begin{array}{l}\text { Process, organize, refine, interpret and } \\
\text { synthesize the information }\end{array}$ & Monitors & $\begin{array}{l}\text { Written reports collecting the } \\
\text { knowledge acquired from } \\
\text { continuous interaction with } \\
\text { "bosses in love" }\end{array}$ & $\begin{array}{l}\text { ABSORPTION } \\
\text { (Potential and } \\
\text { Converted } \\
\text { Absorption } \\
\text { Capability) }\end{array}$ \\
\hline \multirow[t]{2}{*}{ TRANSMIT } & $\begin{array}{l}\text { Transmit information to Prescription } \\
\text { Department Coordinator }\end{array}$ & $\begin{array}{l}\text { Monitors (Issuers) and } \\
\text { Prescription Coordinator } \\
\text { (Receivers) }\end{array}$ & $\begin{array}{l}\text { Meetings and receipt of } \\
\text { information transmitted on } \\
\text { experiences with "bosses in } \\
\text { love" }\end{array}$ & ABSORPTION \\
\hline & $\begin{array}{l}\text { Analyze, evaluate and synthesize } \\
\text { information from the user and consumer } \\
\text { experiences }\end{array}$ & Prescription Coordinator & $\begin{array}{l}\text { Recording, processing, and } \\
\text { synthesis of the information } \\
\text { received from Prescription } \\
\text { Monitors, }\end{array}$ & ABSORPTION \\
\hline $\begin{array}{l}\text { DEFINE THE } \\
\text { SOLUTION }\end{array}$ & $\begin{array}{l}\text { Build a concept that deals with customers' } \\
\text { real needs }\end{array}$ & Prescription Coordinator & $\begin{array}{l}\text { Tacit and explicit knowledge of } \\
\text { product category and } \\
\text { knowledge from monitors } \\
\text { interaction with "bosses in love" }\end{array}$ & $\begin{array}{l}\text { INTEGRATION } \\
+ \text { INNOVATION }\end{array}$ \\
\hline \multirow[t]{6}{*}{$\begin{array}{l}\text { TRANSMIT } \\
\text { INFORMATION }\end{array}$} & $\begin{array}{l}\text { Identify and contact with the Procurement } \\
\text { Manager }\end{array}$ & Prescription Coordinator & $\begin{array}{l}\text { Internal Communication } \\
\text { channels }\end{array}$ & DETECTION \\
\hline & $\begin{array}{l}\text { Transfer the concept to the Procurement } \\
\text { Department }\end{array}$ & $\begin{array}{l}\text { Prescription Coordinator } \\
\text { (issuer) and Procurement } \\
\text { Manager (receiver) }\end{array}$ & $\begin{array}{l}\text { Functional analysis (product's } \\
\text { design requirements) }\end{array}$ & ABSORPTION \\
\hline & $\begin{array}{l}\text { Identify specialized Suppliers with the } \\
\text { capacity to materialize the concept defined }\end{array}$ & Procurement Manager & $\begin{array}{l}\text { Communication \& contact with } \\
\text { potential suppliers }\end{array}$ & DETECTION \\
\hline & $\begin{array}{l}\text { Assign the preparation of the Prototype to } \\
\text { a Specialist Supplier }\end{array}$ & Procurement Manager & Assign Prototype Preparation & INTEGRATION \\
\hline & Manufacture the Prototype & Supplier & $\begin{array}{l}\text { Suppliers' R\&D and Production } \\
\text { Department }\end{array}$ & $\begin{array}{l}\text { INNOVATION } \\
\text { (Product/Proces } \\
\text { s) }\end{array}$ \\
\hline & $\begin{array}{l}\text { Provide "bosses in love" with the prototype } \\
\text { for testing and evaluation }\end{array}$ & Monitors & $\begin{array}{l}\text { Actual product use and } \\
\text { consumption }\end{array}$ & $\begin{array}{l}\text { ABSORPTION + } \\
\text { DETECTION }\end{array}$ \\
\hline \multirow[t]{4}{*}{$\begin{array}{l}\text { PRODUCT } \\
\text { PRESENTATION }\end{array}$} & $\begin{array}{l}\text { Define the specific way to market the } \\
\text { product }\end{array}$ & $\begin{array}{l}\text { Prescription Coordinator } \\
\text { (issuer) and Procurement } \\
\text { Manager (receiver) }\end{array}$ & $\begin{array}{l}\text { Detailed design of how the } \\
\text { product should be marketed }\end{array}$ & INTEGRATION \\
\hline & Produce a limited number of product units & Supplier & $\begin{array}{l}\text { Final preparation of the product, } \\
\text { according to the defined } \\
\text { requirements }\end{array}$ & INNOVATION \\
\hline & $\begin{array}{l}\text { Market the product in a limited number of } \\
\text { supermarkets }\end{array}$ & $\begin{array}{l}\text { Prescription Coordinator } \\
\text { and Monitors }\end{array}$ & $\begin{array}{l}\text { Measurement of success at a } \\
\text { limited number of stores chosen } \\
\text { according to their geographical } \\
\text { location (number of units sold } \\
\text { per day) }\end{array}$ & $\begin{array}{l}\text { INNOVATION + } \\
\text { DETECTION }\end{array}$ \\
\hline & Analyze product's marketing success & $\begin{array}{l}\text { Prescription Coordinator } \\
\text { and Monitors }\end{array}$ & $\begin{array}{l}\text { Product marketing thresholds of } \\
\text { success }\end{array}$ & $\begin{array}{l}\text { DETECTION + } \\
\text { ABSORPTION }\end{array}$ \\
\hline PRESCRIPTION & $\begin{array}{l}\text { Extend the marketing of the product to all } \\
\text { Mercadona's stores }\end{array}$ & $\begin{array}{l}\text { General Management of } \\
\text { Prescription }\end{array}$ & $\begin{array}{l}\text { Analysis tools / Management } \\
\text { reporting }\end{array}$ & ABSORPTION \\
\hline
\end{tabular}




\section{Identify "bosses-consumers in love"}

One of the key principles in Mercadona's culture is the encouragement of dialogue between workers and "bosses" (Mercadona, 2011). All workers develop a "listening and observing" attitude to record and transmit bosses' concerns, suggestions, opinions, and preferences, as factors that enable improvements (Mercadona, 2017). In 2009, with the aim of strengthening communication, Mercadona created a new employee category "monitor". These 250 workers specialized in the study of customer's needs work at supermarkets and are in charge of keeping in direct daily contact with "bosses" based on listening and a friendly approach (Albors, 2015).

Under the principle that it is necessary to "observe the changes in customer behavior and listen to their suggestions to gain their trust and to stay one step ahead of their needs" (Mercadona, 2010), monitors have a threefold function. First, prescribe Mercadona's products. Second, talk to customers exploring and observing their preferences and changes, listening to their suggestions, understanding and recording their needs using this valuable know-how to ultimately offer them solutions and provide suitable answers to gain their trust. The third function consists in the task of reporting by directly and rapidly transferring the information gathered from customers to the Prescription Department Coordinators $(P D C)$-experts working in different product categories that are in charge of choosing the products for sale after defining users' needs-. In 2015, Mercadona had 186 monitors (Silverstein et al., 2015), of which 80 were assigned to dry products and the remainder to fresh/perishable products.

By performing these functions, the monitors develop a series of organizational routines that identify "lead-users' customers" internally called "bosses in love". By listening, observing and interpreting customer behavior at the store and by talking to them, they identify regular customers that "are going to search for a product wherever it is and always consume that product without changing" (Moret, 2014). To begin with, they distinguish between buyers and consumers (customers buying products to consume themselves). They are interested in frequent consumers who are experts with specific and detailed knowledge of the use and ongoing consumption of Mercadona's products. These "bosses in love" are those that know the most about the product, "as they know what they want and are willing to pay for it" (Moret, 2014). Mercadona's objective is to detect, identify and satisfy these customers' needs (Alfonso, 2014:70). According to monitors "when you talk to bosses in love, they can notice all the differences in flavor, aroma, texture, size, format, and presentation of a product" and, therefore, to distinguish and assess improved features (Moret, 2014). In fact, in Mercadona's experience, by obtaining detailed knowledge on their buying and consumer habits, tastes and preferences provide the necessary information to identify what customers really need, as they are also capable of judging innovation and deciding what features can be improved. Mercadona considers that its "bosses in love" represent the most significant unqualified sample of the customers that consume its products. According to a PDC: "there is more value in contacting 3 or 4 bosses in love, than doing a Ph.D. with 20 without this profile" (Climent, 2014).

In this phase, by identifying potential qualified collaborating customers - lead users (Von Hippel, 1986) - Mercadona's "bosses in love" (Mercadona, 2017) the company creates a capability of detection given that contact with customers at stores enables a better understanding of their needs (Amit and Schoemaker, 1993).

\section{File "bosses in love" data}

With the customer's prior consent, the monitors file each "boss in love" identified by Category/Product (i.e.: Dairy Products/Yoghurts). Apart from the customers' contact details, each record also includes their availability to willingly cooperate and collaborate with Mercadona. Data recording is organized and centralized by PDC.

The gathering of data from bosses in love generates the capability of absorption, as the data is structured and therefore improves identification and access (Tham and Luo, 2015).

\section{Invite "bosses in love" to share experiences on the use/consumption of products}

The "bosses in love" are invited to share their products' consumer experiences with monitors at no charge, with the aim of evaluating products. These experiences include products not only these in the 
range but also those which may potentially form part of it. Experiences are shared either at customers' homes or at Mercadona's Living Labs - "Co-innovation Centers" - (Albors, 2015).

This initiative is inserted on Mercadona's open innovation "Apron Strategy" (Mercadona, 2011). Implemented in 2011 it has a twofold objective: firstly, to comprehensively and directly identify customers' specific use of products and, secondly to explore their needs by observing how they cook, wash, clean and take care of their pets. Therefore, by collaborating and interacting directly with them testing and consuming products and thanks to the information compiled by the monitors, Mercadona generates knowledge that, after being absorbed, enables it to innovate in terms of improvements to products or new products' developments.

At Co-innovation Centers, monitors have the opportunity of sharing consumption experiences in real environments. By 2015, Mercadona had invested more than 28.5 million $€$ (Albors, 2015) on them. The centers were built to recreate daily experiences, in which customers use the products and can test them in semi-real environments. The facilities are staffed with 86 monitors specialized in over 20 consumer categories and the products are placed on shelves as they would be found in supermarkets and each center is structured and designed according to the category of products analyzed. For example, the Center specialized in complementary products, breakfast and snacks comprises shelves displaying products of the category; a living/dining room type area for testing products and; finally, a kitchen area where products could be prepared and cooked.

In this phase, Mercadona creates the capability of absorption, as the monitors acquire and assimilate external information and record it in the company's knowledge base to improve processes and products (Cohen and Levinthal, 1990; Zahra and George, 2002).

\section{Compile specific information on "bosses in love" experiences with the products}

Customers' comments and reactions on products' use and consumption, features, qualities, formats, containers, and designs are observed, listened, analyzed, interpreted and recorded "in writing" by monitors. The idea is to perform a detailed analysis of how consumers buy and use the products and generate knowledge of customers' real needs. Everything is tested: new recipes, new container designs, changes in format, new product presentation, etc.

Two methods are used at Co-innovation Centers: First, either the boss in love tests a product that exists in the range and gives his / her opinion, or second, he/she tests a new product suggested by one of Mercadona's suppliers. Frequently, new products are tested using blind tests with two products assessed by a simple questionnaire of two yes/no questions (Nova TV, 2016).

This phase generates a capability of absorption, as it enables to compile specific information on customer experiences. Mercadona acquires and assimilates external information that is recorded on its knowledge database, to improve its products and processes. Mercadona, therefore, acquires a greater capability to learn, because companies that possess high capabilities of absorption also present high learning capabilities by recording external data and converting it into knowledge that can be stored (Verona and Ravasi, 2003; Woisceshyn and Daellenbach, 2005).

\section{Process, organize, refine, interpret and synthesize the information}

Co-innovation Center's monitors analyze, organize, refine, interpret and summarize all the data obtained from their interaction with "bosses in love". As mentioned above, Mercadona prioritizes users' experiences and consumption in real contexts (Wendin; Aström and Stahlbröst, 2015). Visits to customers' homes often detect issues that consumers do not normally report. For example, monitors observed that many customers were buying more than one moisturizing cream and eye make-up remover because they used it a lot and decided to suggest larger packages that were finally made reducing products' cost and price (Monago, 2016).

In this phase, by processing, organizing, refining and synthesizing the data compiled from its monitors' experiences, it is able to generate a capability of absorption. According to Fosfuri and Tribó (2008), they generate two types of absorption capabilities: a potential absorption capability (PAC) that relates to the acquisition and assimilation of external knowledge and, converted absorption capability 
(CAC) that relates to the transformation and exploitation of the knowledge to convert it into a competitive edge.

\section{Transmit information to Prescription Department Coordinator}

The information is transferred to the $P D C$ whose functions include the selection of products for sale (Almenar, 2015). The interaction between the PDCs and the specialized monitors in their categories is constant and ongoing.

This transfer of information based on continuous interaction with "bosses in love" results in Mercadona generating a capability of absorption driven by demand (Murovec and Prodan, 2009).

\section{Analyze, evaluate and synthesize information from user and consumer experiences}

$P D C$ analyze, evaluate and synthesize all the information received. The key idea is to understand what factors/reasons make a product successful/unsuccessful. Based on the information received, the PDC begin working on accurately define customers' needs. Dry products' PDC are organized by Mercadona according to the following categories: Baby Products; Refreshment and Beverages; Dairy products, Desserts and Ice-Creams; Perfumes; Pets and Household maintenance; Aperitifs; Food supplements, Breakfast and Snacks; Cooking Seasoning, Preserves and Pre-cooked Dishes; Milk and Fruit Juices, Coffee, Cocoa and infusions; Cleaning of Clothes and Footwear; Cleaning of Clothes and Homes; Chocolates, Sweets and Refreshments (Mercadona, 2017).

The analysis, evaluation, and synthesis of the information received generates a capability of absorption creating valuable knowledge to be absorbed and providing flexibility and consensus to deal with specific changes (Fernandez; De Pablos and Blanco, 2016).

\section{Build a concept that deals with customers' real needs}

Using this information, the PDC work on potential functional designs of new and existing products, outlining concepts that could provide solutions according to the preferences and real needs detected. This definition is based on both tacit and explicit product "know-how" possessed by Mercadona's PDC on the category of products offered by both Mercadona and its competitors. The result of this process is a product concept that fulfills the requirements and functional requisites detected and specifically absorbed from the direct interaction with "bosses in love". For example, the Co-Innovation Center for "Cooking, Seasoning, Preserves and Pre-cooked dishes" detected that customers demanded a tomato purée with a more home-style flavor. A "boss in love" cooked her own home-style tomato purée at the Co-Innovation Center that once tested was highly popular with other "bosses in love" specialized in this product category. Accordingly, the PDC created a new concept of "Home-style Tomato Purée" whose functional design came from the recipe (Caparrós, 2012; Romera, 2014).

This phase generates a capability of integration, given that the tacit and explicit knowledge of Mercadona's and competitors' product category managed by PDC enables them to build and define concepts whose functional design cater for detected customers' real needs (Gentile; Spiller and Noci, 2007). This phase also creates a capability of innovation, since the proposed concept implies something new or at least, something that responds to a new need that has not been previously detected (Drucker, 2014).

\section{Identify and contact with the Procurement Manager}

Once the Product Concept is designed by the PDC, then they identify and contact Mercadona's Procurement Manager (PrMg), who is in charge of the particular category of products. Mercadona's Commercial Department - which selects the products that makeup company's range - has undergone significant developments in recent years. In 2008, it comprised both Prescription and Procurement with just 50 employees. In June 2017, the Commercial Department, with 650 workers, was divided into two groups: Prescription with 350 employees and Procurement with 300 employees (Mercadona, 2017: 45).

PrMg should be specialists in each product marketed by Mercadona. Their job is to obtain specialized and detailed knowledge of the products, the different market options available that meet customer needs, as well as the specialized national and international suppliers with the capacity to manufacture the products in the category. 
The contact between the PDC and PrMg gives rise to the capability of detection within the organization (Fernandez; De Pablos and Blanco, 2016).

Transfer the concept to the Procurement Department

The concept designed by PDC is sent to Mercadona's PrMg to identify inter-suppliers manufacturers of Mercadona's own brands - and specialist suppliers with the capacity to develop according to the information and requirements received the product improvements identified or create and materialize new or improved solutions.

Communications are therefore established and enable the PrMg, according to the concept defined by the PDC and his/her detailed knowledge of the manufacturers of each product category, to search for the best specialist suppliers of each specific product. These suppliers must have the capacity to assimilate all the information received from Mercadona as well as the R\&D, means of production, capacities, facilities and infrastructures to enable them to define the best solutions at the lowest price, focusing on specific production lines and, finally being capable of successfully satisfying "bosses in love" needs.

In this phase of transfer by the PDC to the PrMg of the product category of information on specialized suppliers capable of providing the defined product concept, the company generates an absorption capability, internally processing the functional analysis that defines product requirements.

\section{Identify specialized Suppliers capable of materializing the concept defined}

The Procurement Department's job is to identify the defined concept's best national or international specialist suppliers. In this regard, there has been a significant evolution at Mercadona since 2013. Before then, it engaged an entire range of related products from its suppliers (normally inter-suppliers) (Blanco and Gutiérrez, 2008). However, Mercadona discovered that although it inters-suppliers were capable of optimally manufacturing some of the products in the category - "first class" products (rated 10 over 10) the quality was lower in other (often rated substantially lower than "10"). Mercadona now expects all its suppliers to be specialists in the manufacture of their products and therefore achieve "10s" in all cases which guarantees excellent user and consumer experiences - although this also implies the search for new specialist suppliers. After notifying its inter-suppliers of the need to obtain a maximum rating for all the products in each category and the response by some that it was impossible, due to the investment required (Maté, 2016), two new figures appeared. First, suppliers specializing in the manufacture of products under the group's own brand and, second, suppliers specializing in original brands that can only supply the specific product to Mercadona. In 2013, Mercadona had 106 inter-suppliers and 100 suppliers per product category and, after adopting the new strategy in 2017, Mercadona had 126 inter-suppliers and more than 2,500 specialized commercial and services suppliers (Mercadona, 2017).

As an example, in 2016 the inter-supplier RNB Cosméticos manufactured practically all Mercadona's sun protection products. Under the new approach, in the summer of 2017, Mercadona incorporated new specialized suppliers manufacturing exclusive products (Table 2). The choice of Dalli Werke was the result of a comprehensive study by the Procurement Department and, after "visiting over 20 manufacturers in Spain and throughout the world, we chose it, due to its high degree of specialization" (Pastor, 2017).

Table 2. Sun protection products' suppliers to Mercadona in the summer of 2017 campaign

\begin{tabular}{|l|l|l|l|}
\hline Supplier & Nationality & Brand & Product Description \\
\hline RNB & $\begin{array}{l}\text { Spanish } \\
\text { (Valencia) }\end{array}$ & Solcare & $\begin{array}{l}\text { Three After sun ranges and four Tanning } \\
\text { ranges }\end{array}$ \\
\hline $\begin{array}{l}\text { Ramón Bolos } \\
\text { Bru }\end{array}$ & $\begin{array}{l}\text { Spanish } \\
\text { (Valencia) }\end{array}$ & Cris \& Cló & $\begin{array}{l}\text { Fast tanning dry touch lotion with 30 } \\
\text { protection factors }\end{array}$ \\
\hline $\begin{array}{l}\text { Mann \& } \\
\text { Schroder }\end{array}$ & Germany & Dulgon & Suntan lotion in different strengths \\
\hline Starhealthcare & $\begin{array}{l}\text { Spanish } \\
\text { (Andalusia) }\end{array}$ & Sisbela & Suntan lotion and face cream \\
\hline Dalli Werke & Germany & Sun Med & Sun spray and lotion in different strengths \\
\hline
\end{tabular}

Source: based on Pastor (2017) 
This phase, by Mercadona's Procurement Department continuously searching for potential suppliers, generates a capability of detection that enables the identification of highly specialized suppliers capable of materializing the defined concepts (Jones; Jimmieson and Griffiths, 2005).

\section{Assign the preparation of the prototype to a specialist supplier}

Once the Procurement Department has identified the optimum highly specialized supplier, it is engaged to prepare a prototype of the provided concept. Frequently, the concept and its defined functional requirements are engaged exclusively for Mercadona, which creates unique and high-quality exclusive products at very competitive prices - internally called "golden screws" - which are extremely popular between customers (Alfonso, 2014).

By assigning prototype's preparation to a specialist supplier, this task generates a capability of integration that enables integrating internal and external knowledge to materialize the defined concept (Jones et al., 2005).

\section{Manufacture the Prototype}

Specialized Suppliers' R\&D departments prepare innovative prototypes that physically materialize Prescription Department's defined concepts. Suppliers work under the basic principles to innovate both, products or processes and the premise that customer's real needs must be met by top-quality products at the lowest price clients are willing to pay for them.

NeoCos Laboratorios was established in 2014 by two 15-years experienced specialist entrepreneurs in the production of hair coloring products. It is Mercadona's manufacturer of hair cosmetic \& coloring products sold under Mercadona's own brand Deliplus. All products are designed and manufactured based on Mercadona's customers real needs - i.e. dying grey hair, changing hair color, highlighting hair color - NeoCos' R\&D department, with a highly specialized staff of chemical and industrial engineers and pharmacists, work to develop and prepare product's prototypes (Nova TV, 2016).

In this phase, a capability of innovation is generated at product level, process level or both (Nonaka; Takeuchi and Kocka, 1999).

\section{Provide the prototype to "bosses in love" for evaluation and testing}

The prototypes are subject to ongoing evaluation by the "bosses in love" who inspired them. It is again through the Prescription Department which in ongoing tests on the prototypes, outline and refines the results to determine whether or not the changes or new products proposed have been achieved and if it is possible to improve and update them. Hence, "bosses in love" play a very active role in the design and development of Mercadona's new products with their opinions and feedback, which, if they are finally accepted, increased substantially their commercial success' probability (Nova TV, 2016).

These tests may be carried out in different ways, although, in all cases, involve prototypes' actual use and consumption. One of the most commonly used formulas consists of blind tests/tastings, in which "bosses in love" test two products individually or in groups, without knowing which one is the new one providing assessments and comments. Monitors should consider that customers tend to be positively biased towards their role as deciders, so it is not enough for them "to like the product" but "they must love it and ask when it will be available ensuring demand and, if this happens with 10 or 15 "bosses in love", that's enough" (Campanario, 2016).

In this phase, a capability of absorption is generated when the monitors make the prototype available to bosses in love involved in the definition of the concept, to experiment, evaluate, assess and validate or reject it through its actual use and consumption. In addition to that, the definition of thresholds regarding bosses in love products' acceptance creates in Mercadona a capability of detection (Lau, 2015).

\section{Define the specific way to market the product}

If an internally defined threshold of "bosses in love" validate the product, the Prescription Department works on how to effectively and efficiently market the product by designing tools and mechanisms that could enable and facilitate its marketing as well as defining the information that is going 
to be provided to customers. The result is a detailed design of how the product should be marketed, which is transmitted to the Procurement Department (Monago, 2016).

This task generates integration capabilities that enable PDC to offer PrMg a detailed design of how they want the product to be marketed comprising features such as size, format, container, color, information provided to the customer, etc. (Herhausen; Binder; Schoegel and Herrmann, 2015).

\section{Produce a limited number of product units}

Suppliers manufacture a limited number of product units including both actual product Innovations as well as innovations in just how the product is marketed. First, regarding, product innovation, it means producing new products that add value by adapting and improving existing products - incremental innovations (i.e. cane sugar added to natural yoghurt) - or creating new ones radical innovations - (i.e. Pocket pureed Fruit; infusions made with cold water; Strawberry aroma vinegar for more hair shine). Second, about innovations in how the product is marketed it comprises: adaptation of containers to make them easier to handle (i.e. adaptation of dye container opening to facilitate faster pouring / adding dispenser to olive oil bottles), to identify (associating make-up varieties with different colors for each category: long-lasting, overall effect; silky and natural effect) and to conserve (airtight seal for wet wipes); to group amounts (i.e. Maxi "Tarta" vanilla and chocolate ice-cream cake in a larger and cheaper 1.8 liter format, thus enabling a cost of $0,11 €$ for ration/portion) and changing formats (reducing the size of hand care cream container so it would fit into customer's bags) (Mercadona, 2010 - 2017).

This task generates an innovation capability, given that suppliers after bosses in love' acceptance produce a limited number of products' units according to defined requirements (Tseng and Lin, 2011).

\section{Market the product in a limited number of supermarkets}

Products are initially launched at one store internally called "laboratory". There are several criteria used to choose it, however preference is given to factors such as geographical proximity to supplier's facilities and suppliers' production capacity. If the marketing of the product is successful, it is extended to a limited number of stores, to check whether similar marketing results are obtained. Product's commercial success is tested emphasizing the number of units sold per store and day (UnSD). If the results are solid and consistent at all stores, the product is gradually supplied to other supermarkets and finally reaches all stores. On the other hand, if the product is not successful, it may be removed.

During this initial limited launching phase, "bosses in love" tests and evaluation continue. In fact, monitors often intensify their work by contacting and calling them for their opinions and even by visiting them at home particularly for perfume and hygiene products. This is the last phase in determining whether a new or improved product has the potential to consolidate or requires refining which is also PDC's responsibility.

Mercadona generates an innovation capability because of the marketing of the product at a limited number of stores. The success of the product is measured by the number of units sold per day and store (Thomke and Von Hippel, 2002). In addition to that, the definition and measurement of the number of units sold per store/day allow detecting product's commercial success (Waller and Fawcett, 2013). So here detection capability is also reached.

\section{Analyzing product's marketing success}

Product's Marketing success measurement criterium is the number of UnSD which is coherent with innovation success tools such as Kantar's World Panel Record on food product innovation. In 2013, two Mercadona's own brand innovative products: "Pasta mix snack" and "Carrot rooibos tea" were in the ranking. The radar is a tool that acknowledges the most successful innovations and identifies the common patterns amongst them. The radar considers that an innovation exists when the launched product contributes a new feature to the category and it is successful when it exceeds the annual average market penetration (Kantar World Panel, 2014). Mercadona repeated its success in 2016 with three products in the ranking (Kantar World Panel, 2017). In addition to that, Mercadona considered a product a success if it does not damage or cannibalize the sale of other products in the same category and increases sales and market share of both (Moret, 2014). 
Mercadona launched Smoothies - a natural presentation of pureed fruit and vegetables without preservatives or colorants - in 2016. The Prescription Department detected that customers were demanding "a fresh and healthy product that was tasty and inviting". After assigning the preparation of a prototype to Mercadona's intersupplier, Verdifresh, the product was launched in February and, in August was extended to all stores. It was firstly tested in a few stores and at the Co-innovation Center for a month, where the results were studied. The opinions of the "bosses in love" resulted in two of the seven references being dropped and one new product chosen because it contained ginger since customers were demanding ingredients that are more natural and were concerned with sugar. The products were then tested for a further two months in stores in three areas of Madrid and then extended to Valencia. Mercadona's objective was to sell 7 and, on average, 30 UnSD were sold, thus confirming product's success (Campanario, 2016b).

In this phase Mercadona generates both, the capability of detection and the capability of absorption by defining and measuring success thresholds for product marketing determining its sales' potential (Tsai, 2009).

\section{Extend the marketing of the product to all Mercadona's stores}

In this final phase, the product becomes available as part of the "efficient range" that Mercadona prescribes to its customers at all its stores. The suppliers then initiate and install definite production lines. It should be highlighted that not all innovations are permanent but evolve quickly to adjust to the everchanging and dynamic customers' needs. In fact, there are exclusive novelties for customers' specific needs in summer and Christmas (Mercadona,2017).

For instance, in 2014, Mercadona launched its "Summer Shampoo", a novelty resulting from the information obtained at the "Perfume" Co-innovation Center. Customers demanded, "a fresher shampoo that they could use daily during summer that would leave their hair soft and protected from the sun at a reasonable price". After defining the concept, the product's prototype was engaged and produced by Mercadona's supplier of shampoos - Maverick - and, after the relevant tests, it was included on supermarket shelves at an approximate price of $1 €$, reaching total sales of 12,000 units per day (Caparrós, 2014).

By using management analysis and reporting tools, the Prescription General Management generates the capability of absorption by extending products to all stores in the chain (Forés and Camisón, 2016).

As observed in the entire process, "bosses in love" suggestions and experiences constitute authentic differential leverages for new products' improvement and development (approximately 5\% of Mercadona's total references per year) creating "proximity and trust that generates loyalty" as customers identify themselves more with its range (Zaragozá, 2014). This contributes to consolidating Mercadona's competitive edge, as it is able to anticipate and respond quicker to customers' real and changing needs thanks to the agile and rapid introduction of exclusive designs and products manufactured by specialized Suppliers that are highly successful because its customers have suggested them. Table 3 summarizes the novelties incorporated to Mercadona's range of products as a result of the number of customers/sessions carried out at Co-innovation Centers.

Table 3. Impact of the activities carried out at Mercadona's Co-innovation Centers

\begin{tabular}{|l|l|l|l|l|l|l|}
\hline & 2011 & 2012 & 2013 & 2014 & 2015 & 2016 \\
\hline $\begin{array}{l}\text { Novelties } \\
\text { resulting from } \\
\text { collaboration } \\
\text { (new/improved } \\
\text { products) }\end{array}$ & $\begin{array}{l}100- \\
\text { innovation } \\
\text { of } 75 \\
\text { products of } \\
\text { the range - }\end{array}$ & 250 & 400 & $100 / 450$ & 100 & $\begin{array}{l}300 \text { novelties (150 } \\
\text { co-innovation } \\
\text { products) and 350 } \\
\text { improvements in } \\
\text { the range }\end{array}$ \\
\hline $\begin{array}{l}\text { Customers } \\
\text { / sessions }\end{array}$ & $\begin{array}{l}1,200 \\
\text { customers }\end{array}$ & $\begin{array}{l}7,000 \\
\text { customers }\end{array}$ & $\begin{array}{l}9,000 \\
\text { customers }\end{array}$ & $\begin{array}{l}6,000 \\
\text { sessions }\end{array}$ & 5,500 sessions & 6,100 sessions \\
\hline Centers & 11 & 11 & 12 & 12 & 12 & 13 \\
\hline
\end{tabular}

Source: own data based on Mercadona Annual Financial Statements (2010 - 2017) 


\section{Mercadona's Co-innovation Model}

Mercadona's Co-innovation Model is comprised of 19 tasks that involve a joint effort of co-creation with Bosses in love, Workers (employees, monitors, PDC and PrMg) and suppliers. It is currently amongst the most innovative international corporate models, based on a process of firstly innovating and then implementing (Silverstein et al., 2015). Under this model, the organizational routines developed by Mercadona are focused on the creation and development of a series of dynamic capabilities that have been described in this work. It is a circular model, based on the scheme developed by Birchall and Tovstiga (2005) (Figure 2). It is important to note that the process does not end with the implementation, introduction, and availability of the novelty at all the stores, as Mercadona staff is required to observe closely customer's reactions to the new products, as well as their comments and suggestions for improvement, which re-initiates again the entire process.

Figure 2. Mercadona's Dynamic capability building cycle

\section{LEARNING}

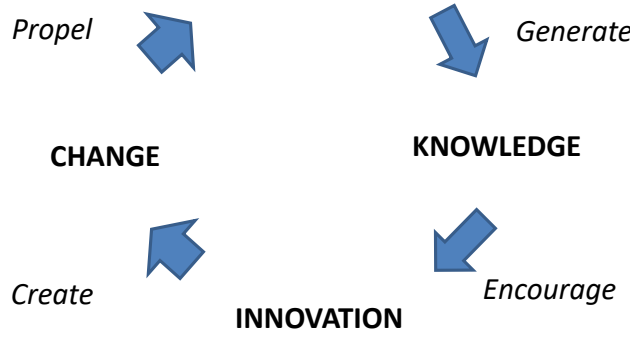

Source: Adapted from Birchall and Tovstiga (2005)

\section{Discussion and Conclusions}

Mercadona's competitive edge is a consequence of its pursuit of excellence of service and its determination to define a rational and complete - efficient range - of low prices and maximum quality solutions, in conjunction with its customers and specialized suppliers with an impeccable consumer experience that adapts and provides specific and rapid response to its bosses' real, dynamic and everchanging needs. This competitive edge is the result of correct solutions in all its product lines that facilitates optimum shopping and generates close customer relations, who identified with the range become loyal customers. In this way, Mercadona has consolidated its competitive advantage and it is the most profitable chain of supermarkets in Spain (Figure 3).

Figure 3. Supermarket profitability according to $\mathrm{m}^{2}$ of commercial surface ( $€$ net turnover in 2015)

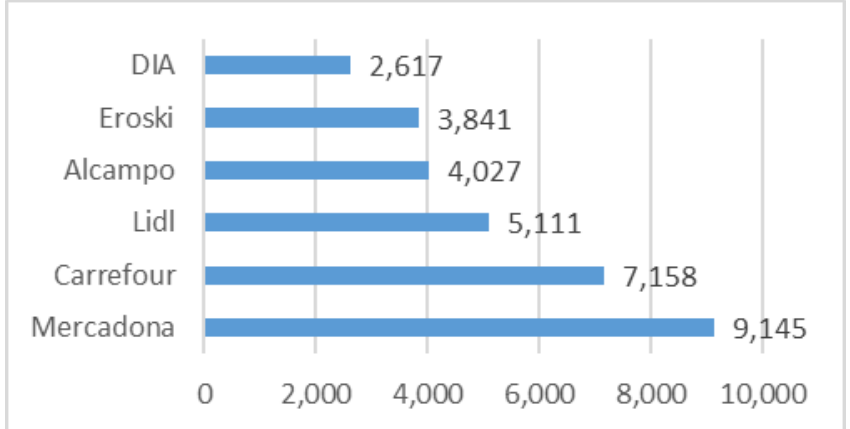

Note: The Carrefour surface area does not include textiles, leisure or information technology, but only consumer goods

Source: Valero and Escudero (2016)

In fact, almost 9 out of every 10 Spanish households (87.4\%) shop at Mercadona (Kantar World Panel, October 2016). As observed in this work, one of the determining factors of this success has been the implementation of an open co-innovation model based on customers' direct experiences with products 
conducted on living labs where the identified lead users generate knowledge that once absorbed and integrated is used by Mercadona's highly specialized suppliers. This approach has enabled the development of a series of dynamic capabilities that have helped to better adapt its range to the new and constantly changing customer's needs. Hence, Mercadona offers a unique and exclusive range of products that is constantly and permanently updated, resulting in Co-innovation as a "key differentiating tool for competitiveness", in which the "boss" acquires a leading role in the development and improvement of solutions (Mercadona, 2016).

This direct customer participation model firstly enables Mercadona to increase the probability that the products offered under its own brands were more accepted and attractive than leading recognized brands (Silverstein et al., 2015). Secondly, it also helps customers to perceive them differently, and achieve a positive welcome: "if you listen to your customers, it is easier to innovate successfully, with fewer risks; success is based on knowing how to connect" (Lillo, 2016). Actually, not only in terms of innovation $0.61 \%$ in the Food sector vs. $0.89 \%$ in Mercadona's Food and Beverages' Inter-suppliers - but also in terms of success rates - in which only one of every four products launched by suppliers and commercialized by retail companies lasts for more than one year $(24 \%)$ whereas at Mercadona, the figure rises to $82 \%$ (four out of every five innovations) (Institut Cerdá, 2016) - Mercadona is very successful. Furthermore, in terms of customer satisfaction and perception, according to consultancy firm TNS, Mercadona's products held top positions in terms of value for money perceived by customers (Silverstein et al., 2015).

As described above, to guarantee better adjustment and ensure a quick response, Mercadona works constantly to listen to and observe its "bosses", based on a relationship of proximity and trust. This close relationship is achieved "on the shop floor" (workers and, specifically, monitors) and "putting an apron on with them" (at "Co-innovation Centers" and by accompanying customers to where they specifically use the products). Processing of the information obtained enables to detect areas of improvement, offer specific solutions and pursue excellence of service with its range based on consumer experiences with products, which is a key factor in customer satisfaction (Mercadona, 2012). Actually, customers even become prescribers of products by "word of mouth" that is a key asset for a company which does not invest in conventional advertising (Alfonso, 2014; Almenar, 2015).

Mercadona is, in fact, the company with the second highest national reputation and the highest reputation in the Retail Industry (Merco, 2016). In Spain, it is not only the leading firm in its sector, but also the highest rated retail company according to a survey carried out by IPSOS (2014), in which it was the company that most people would recommend (74\%) vs. El Corte Inglés $(47 \%)$ and Dia $(41 \%)$ - the most preferred $(82 \%)$ vs. Carrefour $(52 \%)$ and El Corte Inglés $(51 \%)$. Customers also valued the high quality of its products (82\%) - compared with El Corte Inglés (71\%) and Carrefour (53\%) - and the service received at its supermarkets $(76 \%)$ vs. El Corte Inglés $(71 \%)$ and Carrefour $(47 \%)$-. In fact, Mercadona was rated as the company with the highest quality products, well above its competitors, with $75 \%$ of the votes that classified its product quality as "good or very good". Finally, it is users' highest valued supermarket for its value for money (Ontwice, 2015).

On the international scene, the Boston Consulting Group prepared an index on company performance, based on a survey of 32,000 consumers in the U.S., U.K., Germany, France and Spain. The survey ranked companies according to - spontaneous and non-spontaneous - or prompted recommendations and the criticism received. Among grocers, Mercadona held top position, with a result of $54 \%$ vs the sector average of $24 \%$, well above "the traditional "incumbent" supermarkets chains in the different countries across Europe and the U.S. - Carrefour and Leclerc in France, Aldi in Germany, Tesco and Sainsbury in the UK and Walmart in the U.S." (Silverstein et al., 2015: 182). According to the survey, $66 \%$ of consumers stated that Mercadona provided a "great" or "good" experience, placing it over Europe's leading discounters Aldi and Lidl. Indeed, "it puts it on a par with feted consumer brands such as Apple's iPhone" (Silverstein et al., 2015:183).

Finally, in terms of corporate results, there are three relevant issues to highlight. First, the constant reduction in the price of its prescribed "shopping trolley", being able to sell a higher quantity at a lower price every year and making more profit - the company achieved a total savings of 4,700 million $€$ from 2009 to 2016 - while maintaining profitability in its value chain. Second, the optimization of processes has 
increased profits even more than sales (Table 4). Third, the constant renewal of its range, with over 400 new products per year whereas other major food brands rarely reach around 120 products (Zaragozá, 2014; Institut Cerdà, 2016).

Table 4. - Mercadona Results (2008 - 2016)

\begin{tabular}{|c|c|c|c|c|c|c|c|c|c|}
\hline & 2008 & 2009 & 2010 & 2011 & 2012 & 2013 & 2014 & 2015 & 2016 \\
\hline $\begin{array}{l}\text { Units sold } \\
\text { (millions of } \\
\text { Kiloliters) }\end{array}$ & 7.400 & $\begin{array}{l}8,000 \\
(+8 \%)\end{array}$ & $\begin{array}{l}8,532 \\
(+7 \%)\end{array}$ & $\begin{array}{c}9,101 \\
(+7 \%)\end{array}$ & $\begin{array}{l}9,647 \\
(+6 \%)\end{array}$ & $\begin{array}{l}9,845 \\
(+2 \%)\end{array}$ & $\begin{array}{l}10,103 \\
(+3 \%)\end{array}$ & $\begin{array}{l}10,649 \\
(+5 \%)\end{array}$ & $\begin{array}{l}11,071 \\
(+4 \%)\end{array}$ \\
\hline $\begin{array}{c}\text { Gross sales } \\
\text { (Turnover) } \\
\text { Millions of euros }\end{array}$ & $\begin{array}{l}15,379 \\
(+10 \%)\end{array}$ & $\begin{array}{l}15,505 \\
(+1 \%)\end{array}$ & $\begin{array}{l}16,485 \\
(+6 \%)\end{array}$ & $\begin{array}{l}17,831 \\
(+8 \%)\end{array}$ & $\begin{array}{l}19,077 \\
(+7 \%)\end{array}$ & $\begin{array}{l}19,812 \\
(+4 \%)\end{array}$ & $\begin{array}{l}20,161 \\
(+2 \%)\end{array}$ & $\begin{array}{l}20,831 \\
(+3 \%)\end{array}$ & $\begin{array}{l}21,623 \\
(+4 \%)\end{array}$ \\
\hline EBITDA & 838 & 725 & 1,000 & 1,040 & 1,082 & 1,060 & 1,070 & 1,120 & 1,092 \\
\hline $\begin{array}{l}\text { Gross profit } \\
(\text { millions of } € \text { ) }\end{array}$ & $\begin{array}{c}444 \\
(-6 \%) \\
\end{array}$ & $\begin{array}{c}360 \\
(-19 \%) \\
\end{array}$ & $\begin{array}{c}564 \\
(+57 \%) \\
\end{array}$ & $\begin{array}{c}669 \\
(+19 \%) \\
\end{array}$ & $\begin{array}{c}710 \\
(+6 \%) \\
\end{array}$ & $\begin{array}{c}718 \\
(+1 \%) \\
\end{array}$ & $\begin{array}{c}738 \\
(+3 \%) \\
\end{array}$ & $\begin{array}{c}810 \\
(+10 \%) \\
\end{array}$ & $\begin{array}{c}803 \\
(-1 \%) \\
\end{array}$ \\
\hline $\begin{array}{c}\text { Net profit } \\
(\text { millions of } € \text { ) }\end{array}$ & $\begin{array}{c}320 \\
(-5 \%)\end{array}$ & $\begin{array}{c}270 \\
(-16 \%) \\
\end{array}$ & $\begin{array}{c}398 \\
(+47 \%)\end{array}$ & $\begin{array}{c}474 \\
(+19 \%)\end{array}$ & $\begin{array}{c}508 \\
(+7 \%)\end{array}$ & $\begin{array}{c}515 \\
(+1 \%)\end{array}$ & $\begin{array}{c}543 \\
(+5 \%)\end{array}$ & $\begin{array}{c}611 \\
(+12 \%)\end{array}$ & $\begin{array}{c}636 \\
(+4 \%) \\
\end{array}$ \\
\hline
\end{tabular}

Source: Mercadona Annual Financial Statements (2008 - 2016)

\section{Limitations and Direction for future research}

Finally, regarding limitations, the authors are aware of case study methodology limits, particularly if the research is based on just a single case. Therefore, the extension of the results to the retailing industry is limited due to the fact that the Innovation Model described is very idiosyncratic and has been developed from and according to Mercadona's values and culture. That being said, Mercadona's results are so spectacular that we consider the detailed description of the model stimulating for both academics and managers.

Regarding future research, it would be of interest linking "Dynamic Capabilities" theoretical Framework with product innovation developed in a context of open innovation as a source of competitive advantage in companies from different industries including industrial and service-related sectors.

\section{Acknowledgements}

Authors would like to thank Research Project V707 From Clever Energy Campus CEI URJC-UAH as well as URJC's Research Vice-rectorship and Jeff Callow for their support in paper's translation.

\section{References}

Albors, J. (2015). Bringing your customers to the Lab: Barriers and Facilitators for Consumer Coinnovation. Paper presented on PICMET Conference. August 2015

Alimarket (2016). Informe 2016 del mercado de los supermercados. Madrid

Alfonso, J. (2014). Historia de un éxito: Mercadona. Editorial Conecta. Madrid

Almenar, E. (2016). El poder de las marcas del distribuidor. El caso de Bosque Verde Tesis Doctoral. Retrieved: http://hdl.handle.net/10803/349220.

Amit, R., Schoemaker, P. J. (1993). Strategic assets and organizational rent. Strategic Management Journal, 14(1), 33-46.

Barney (1991). Firm resources and Sustained Competitive Advantage. Journal of Management, 17,99-120.

Birchall, D., Tovstiga, G. (2005). Capabilities for Strategic Advantage: Leading Through Technological Innovation. Editorial Palgrave McMillan. New York

Blanco, M., Gutierrez, S. (2008). El Modelo de Gestión de Calidad Total en el sector de la Distribución Comercial en España: El caso Mercadona. Universia Business Review. Primer Trimestre 2008, 40-63.

Brines, J., Onrubia, S. (2016, September 8). Heineken fabrica una marca a medida para Mercadona. Expansión. Retrieved:http://www.expansion.com/empresas/distribucion/2016/09/08/57d06aa722601d32388b45a2.html

Campanario, I. (2016, September 17). La trastienda de la I+D de Mercadona. El Correo de Andalucía. Retrieved: http://elcorreoweb.es/economia/la-trastienda-de-la-i-d-de-mercadona-CY2166073

Campanario, I. (2016b, September 17). Inventos vs. Innovación. El Correo de Andalucía. Retrieved: http://elcorreoweb.es/economia/inventos-vs-innovacion-FY2166117 
Caparrós, A. (2012, July 9). El laboratorio de ideas de Mercadona. ABC Suplemento Empresa. Retrieved: http:/ / www.abc.es/20120709/economia/abci-mercadona-juan-roig-secreto-201207091303.html

Caparrós, A. (2014, August 25). Así nacen los nuevos productos de Mercadona. Abc Comunidad Valenciana. Retrieved: http://www.abc.es/local-comunidad-valenciana/20140825/abci-centros-coinnovacion-mercadona201408250926.html

Chesbrough, H. W. (2006). Open innovation: The new imperative for creating and profiting from technology. Harvard Business Press. Boston, Massachusetts

Climent, M. (2014, July 15). Formato "maxi" y arroz, dos sorpresas del helado esta campaña. El Mundo. Retrieved: http:/ / www.elmundo.es/economia/2014/07/14/53c02b37ca4741ec4b8b458d.html

Cohen, W. M., Levinthal, D. A. (1990). Absorptive capacity: A new perspective on learning and innovation. Administrative Science Quarterly, 128-152.

Drucker, P. (2014). Innovation and entrepreneurship. Routledge.

Eisenhardt, K.M. (1989). Building theories from case study research. Academy of Management Review, 14, 532-550.

Fernández Valero, G., de Pablos Heredero, C., \& Blanco Callejo, M. (2016). La generación de capacidades dinámicas a través de la homologación de proveedores: análisis de buenas prácticas. Harvard Deusto Business Research, 5(2), 107-121.

Følstad, A. (2008). Towards a living lab for development of online community services. Report.

Forés, B., Camisón, C. (2016). Does incremental and radical innovation performance depend on different types of knowledge accumulation capabilities and organizational size? Journal of Business Research, 69(2), 831-848.

Fosfuri, A., Tribó, J. A. (2008). Exploring the antecedents of potential absorptive capacity and its impact on innovation performance. Omega, 36(2), 173-187.

Franke, N., Keinz, P., Steger, C. J. (2009). Testing the value of customization: when do customers really prefer products tailored to their preferences? Journal of marketing, 73(5), 103-121.

Gentile, C., Spiller, N., Noci, G. (2007). How to sustain the customer experience: An overview of experience components that co-create value with the customer. European Management Journal, 25(5), 395-410.

Hancock, D. R., Algozzine, B. (2015). Doing case study research: A practical guide for beginning researchers. New York, NY: Teachers College Press.

Herhausen, D., Binder, J., Schoegel, M., Herrmann, A. (2015). Integrating bricks with clicks: retailer-level and channellevel outcomes of online-offline channel integration. Journal of Retailing, 91(2), 309-325.

$\mathrm{Hu}$, M.C. (2012). Technological innovation capabilities in the thin film transistor-liquid crystal display industries of Japan, Korea, and Taiwan. Research Policy, 41(3), 541-555.

Ipsos (2013). Reputación Corporativa de las Empresas en España. Informe Periodistas Junio. Retrieved: http://www.ipsos.es/sites/all/themes/ipsos/docus/KAR/kar_ola13_info_periodistas_201306.pdf

Jones, R. A., Jimmieson, N. L., Griffiths, A. (2005). The impact of organizational culture and reshaping capabilities on change implementation success: The mediating role of readiness for change. Journal of Management Studies, 42(2), 361-386.

Información (2017). Mercadona y Chocolates Valor consolidan su relación con la línea de bombones Senzza. Retrieved: http://www.diarioinformacion.com/economia/2017/01/31/mercadona-chocolates-consolidanrelacion-linea/1855297.html

Institut Cerdà (2016). El valor de la innovación conjunta. Retrieved: https://www.mercadona.es/document/es/elvalor-de-la-innovacion-conjunta.pdf

Kantar World Panel (2014-2017). Cuotas de Mercado de la Distribución. Retrieved: https://www.kantarworldpanel.com/es/grocery-market-share/spain

Kantar World Panel (2014). Informe Radar de la Innovación.

Kantar World Panel (2017). Informe Radar de la Innovación.

Lau, K. J. (2015). New age capitalism: making money East of Eden. University of Pennsylvania Press.

Lazonick, W., Prencipe, A. (2005). Dynamic capabilities and sustained innovation: strategic control and financial commitment at Rolls-Royce plc. Industrial and Corporate Change, 14(3), 501-542.

Lee, H. H., Chang, E. (2011). Consumer attitudes toward online mass customization: An application of extended technology acceptance model. Journal of Computer-Mediated Communication, 16(2), 171-200.

Lillo, I. (2016, June 17). Jorge Romero: “El Jefe es el cliente, es imposible innovar si no se le escucha”. Diario Sur. Retrieved:

http:/ / www.diariosur.es/malaga-capital/201606/17/jorge-romero-jefe-cliente-20160617135828.html

Maté, V. (2016, December 27). Mercadona retoca su estrategia y da entrada a nuevos proveedores. El País. Retrieved: https://economia.elpais.com/economia/2016/12/26/actualidad/1482748780_641931.html.

Mercadona (2007 - 2017). Memorias y Cuentas Anuales Mercadona.

Merco (2017). Informe Empresas del Monitor Empresarial de Reputación Corporativa. Retrieved: 
http://www.merco.info/es/actualidad/inditex-mercadona-santander-repsol-y-bbva-son-las-cinco-empresascon-mejor-reputacion-corporativa-d

Monago, T. (2016, December 28). El surtido nace en el cliente. Diario de Sevilla. Retrieved: http:/ / www.diariodesevilla.es/economia/surtido-nace-cliente_0_1094590902.html

Moret, X. (2014, January 29). La receta de Mercadona: que innove el cliente. Las Provincias. Retrieved: http://www.lasprovincias.es/v/20140129/economia/innove-cliente-20140129.html

Murovec, N., Prodan, I. (2009). Absorptive capacity, its determinants, and influence on innovation output: Crosscultural validation of the structural model. Technovation, 29(12), 859-872.

Nelson, R., Winter, S. (1982). "An evolutionary theory of economic change", Cambridge: The Belknap Press of Harvard University Press.

Nonaka, I., Takeuchi, H., Kocka, M. H. (1999). La organización creadora de conocimiento: cómo las compañias japonesas crean la dinámica de la innovación (pp. 61-103). Oxford University Press. Mexico D.F.

Nova TV (2016). ¿Coinnovamos? Innovación colaborativa en Mercadona. Retrieved: https://vimeo.com/175345571

Okhuysen, G. A., Eisenhardt, K. M. (2002). Integrating knowledge in groups: How formal interventions enable flexibility. Organization Science, 13(4), 370-386.

Ontwice (2015). Estudio Supermercados Retail, la evolución del on al off. Retrieved: http://ipmark.com/mercadonalider-retail-on-y-off/

Pastor, E. (2017, April 29). Mercadona encuentra nuevos proveedores de productos solares. Retrieved: https://valenciaplaza.com/Mercadona-encuentra-nuevos-proveedores-productos-solares

Pine, B. J., Gilmore, J. H. (1999). The experience economy: work is theatre E every business a stage. Harvard Business Press. Boston, Massachusetts.

Romera, J. (2014, June 17). Mercadona lidera la innovación en España con 400 lanzamientos al año. El Economista. Retrieved: http://www.eleconomista.es/emprendedores-innova/noticias/5868099/06/14/Mercadona-liderala-innovacion-en-Espana.html

Silverstein, M.J., Bolden, D., Jacobsen, R., Sajdeh, R. (2015). Rocket: Eight Lessons to secure infinite Growth. McGrawHill Education.

Tham, C. K., Luo, T. (2015). Quality of contributed service and market equilibrium for participatory sensing. IEEE Transactions on Mobile Computing, 14(4), 829-842.

Thomke, S., Von Hippel, E. (2002). Customers as innovators: a new way to create value. Harvard Business Review, 80(4), 74-85.

Teece, D. J., Pisano, G., Shuen, A. (1997). Dynamic capabilities and strategic management. Strategic Management Journal, 509-533.

Tsai, K. H. (2009). Collaborative networks and product innovation performance: Toward a contingency perspective. Research policy, 38(5), 765-778.

Tseng, Y. H., Lin, C. T. (2011). Enhancing enterprise agility by deploying agile drivers, capabilities and providers. Information Sciences, 181(17), 3693-3708.

Valero, M., Escudero, J. (2016, November 1). Mercadona es la cadena más rentable por metro cuadrado: triplica en ventas a DIA. Retrieved: https://www.elconfidencial.com/empresas/2016-11-01/mercadona-carrefour-diahipercor-supermercados-rentabilidad_1283153/

Verona, G., Ravasi, D. (2003). Unbundling dynamic capabilities: an exploratory study of continuous product innovation. Industrial and Corporate Change, 12(3), 577-606.

Von Hippel, E. (1986). Lead users: a source of novel product concepts. Management Science, 32(7), 791-805.

Waller, M.A., Fawcett, S.A. (2013). Data Science, Predictive Analytics and Big Data: A revolution that will transform Supply Chain Design and Management. Journal of Business Logistics. 34 (4), 249-252.

Wendin, K., Aström, A., Stahlbröst, A. (2015). Exploring differences between centrally located and home use test in a living lab context. International Journal of Consumer Studies, Vol (39), 230-238.

West, M. A. (Ed.). (2016). The psychology of meditation: research and practice. Oxford University Press.

Woiscehyn, J., Daellenbach, U. (2005). Integrative capability and technology adoption: evidence from oil firms. Industrial and Corporate Change, 14(2), 307-342

Yin, R. K. (1994). Case study research: design and methods. International Educational and Professional Publisher. Thousand Oaks, California.

Zahra, S. A., George, G. (2002). Absorptive capacity: A review, reconceptualization, and extension. Academy of management review, 27(2), 185-203.

Zaragozá, J.L. (2014, March 3). Innovaciones del “jefe” en Mercadona. Levante el Mercantil Valenciano. Retrieved: http:/ / www.levante-emv.com/mercantil-valenciano/2014/03/17/innovaciones-jefe/1090952.html 